\title{
APLIKASI PEMESANAN DAN PENYEWAAN TENDA BERBASIS ONLINE PADA HAIKEL TENDA BANJARMASIN
}

\author{
Herry Adi Chandra \\ Fakultas Teknologi Informasi \\ Universitas Islam Kalimantan Muhammad Arsyad Al Banjari Banjarmasin \\ email: herrysbc@gmail.com
}

\begin{abstract}
ABSTRAK
Perkembangan teknologi komputer dan komunikasi di Indonesia sudah sangat pesat sekali, hal ini terlihat dari penggunaan teknologi dan informasi yang dahulu hanya digunakan pada perusahaanperusahaan berskala besar, sekarang penggunaan teknologi dan informasi sudah digunakan oleh perusahaan- perusahaan berskala kecil. Teknologi yang terus berkembang akan memberikan dampak suatu perubahan pada sebuah sistem, dimana suatu sistem yang biasa dilakukan secara manual, kini sistem tersebut dapat dilakukan dengan mudah secara komputerisasi.aplikasi berbasis online belakangan ini makin marak keberadaannya dalam kehidupan sehari-hari. Penggunaannya pun beragam dari sebagai sarana transaksi yang mudah, hingga penyampaian informasi. karena diera yang moderen ini sebuah sistem yang berbasis online yang banyak dipergunakan oleh penyedia jasa penyewaan untuk memudahkan pelanggan dalam memesan barang tanpa perlu dating ketempat penyewaan, seperti sistem informasi pemesanan dan penyewanan tenda yang berbasis online ini. Keberadaan semakin hari semakin diminati dan keberadaannya turut berkembang.Haikel Tenda Banjarmasin sebelumnya masih menggunakan media buku dalam hal menyampaikan laporan hasil transaksi, akan tetapi penerapannya masih bersifat manual. Sehingga sistem informasi ini akan dikembangkan secara komputerisasi serta lebih modern dengan media online , agar dapat mempermudah admin untuk melaporkan kepada pemilik data transaksi harian, bulanan, dan tahunan serta barang yang banyak diminati oleh pelanggan.
\end{abstract}

Kata Kunci : Aplikasi Pemesanan ,Berbasis Online, Teknologi Dan Informasi

\section{PENDAHULUAN}

Perkembangan usaha pelayanan jasa penyewaan perlengkapan yang menawarkan berbagai macam produk-produk seperti tenda,Pangung dan dekorasi waktu kewaktu mulai meningkat. Pengguna jasa perlengkapan pada berbagai acara diantaranya pesta pernikahan,perpisahan sekolah,akikahan,konser musik dan acara lainnya,konsumen dapat mencari informasi tentang penyewaan jasa tenda dan mendatangi langsung untuk mengisi formulir penyewaan serta melakukan pembayaran.Penyewaan merupakan suatu jenis pelayanan jasa, seperti pada Haikel tenda. Dengan proses kegiatan penyewaan mulai dari pemberian informasi nya penyewaan menggunakan media pamphlet, sebagai cara untuk mendapatkan konsumen. Proses pengelolaan perlengkapan dengan pencatatan, belum memanfaatkan kecangihan teknologi.Persaing dunia usaha menyebabkan
Haikel Tenda mulai mengalami penurunan omset, dari hasil catatan laporan transaksi setiap tahun dan dari jumlah transaksi yang ada, perusahaan dituntut untuk dapat menyediakan pelayanan yang lebih optimal dengan pemanfaatan teknologi informasi.

Berdasarkan hasil penelitian pada perusahaan Haikel Tenda, perusahaan mengalami penurunan jumlah transaksi yang signifikan, Hal tersebut disebabkan kendala yang terjadi saat ini yaitu sulitnya akses pada saat konsumen mencari informasi karena hanya mngunakan pamphlet, kartu nama, dan mulut ke mulut sebagai media promosi, pengecekan stock perlengkapan yang tidak sesuai dengan data stock perlengkapan, jumlah pengiriman perlengkapan tidak sesuai dengan jumlah yang diminta konsumen ,pendataan kondisi pengembalian perlengkapan yang tidak sama dengan perlengkapan yang telah dikirim yang menyebabkan stock persediaan perlengkapan 
tidak sesuai dengan data perlengkapan yang telah dikirim.

Oleh karena itu Media online (Web) merupakan suatu sarana yang efektif untuk mempertemukan segala lapisan masyarakat baik teknik, dengan metode penyajian data dan informasi. Informasi yang dapat disajikan dalam media online sangatlah beragam. Hampir dari segala sesuatu yang berhubungan dengan kehidupan kita sehari-hari. Dari mulai transaksi E-Commerce yang termasuk didalamnya pemesanan atau jual beli secara online, atau hanya sekedar system informasi.hampir semua orang saat ini telah mengakses internet, sehingga bukan mustahil internet digunakan juga sebagai sebuah media dalam mengiklankan produk-produk disebuah perusahaan.

Perusahaan "Haikel Tenda" didirikan untuk membantu dan kerja sama kepada masyarakat luas baik golongan menengah kebawah dan menengah keatas dalam bentukbentuk layanan kepentingan pesta pernikahan, pertemuan- pertemuan, panggung-panggung show dan untuk keperluan yang lain dengan ketentuan kerja sama sewa menyewa. Oleh karena itu diperlukan lebih banyak sarana informasi untuk mengetahui tentang harga, jenis barang atau yang lainnya, secara akurat dan dapat diakses secara online 24 jam.

Dari hasil penelitian, perlu diadakan pengembangan untuk membangun sistem informasi penyewaan sehingga permasalahan tersebut diatas dapat diselesaikan untuk itu diangangkat menjadi materi skripsi dengan judul “ Sistem Informasi Pemesanan Dan Penyewaan Tenda Berbasis Online Pada Haikel Tenda Banjarmasin “.

\section{Rumusan Masalah}

Bagaimana cara mempermudah konsumen untuk mendapatkan informasi penyewaan dan melakukan pemesanan tanpa harus datang ke Haikel tenda, dan membuat hasil rancangan sistem informasi pemesanan dan penyewaan Tenda berbasis web kedalam bahasa pemrograman sehingga membentuk suatu program aplikasi yang dapat membantu dalam proses kegiatan penyewaan perlengkapan pesta , seta mengurangi tingkat kesalahan karyawan dalam pencatatan barang pada saat pengiriman dan pengembalian.

\section{Tujuan Penelitian}

Untuk mempermudah memberikan informasi kepada konsumen tentang produk-produk, harga-harga peralatan Tenda,Panggung,dll yang ditawarkan dan melakukan pemesanan, mengurangi kesalahan pada saat melakukan pengiriman perlengkapan karena berkas dokumen penyewaan yang hilang atau rusak menyebabkan waktu dalam pengiriman terhambat, serta merubah sistem manual menjadi sistem komputerisasi yang berbasis online ( web ) sehingga dapat menghasilkan sistem yang lebih efisien dan efektif.

\section{Manfaat pembuatan}

Selain tujuan pembuatan di atas, pembuatan ini juga memiliki manfaat sebagai berikut :

1. Mempermudah pemilik perusahaan tenda dalam peroses pengawasan perusahaan.

2. Mempermudah Pemilik dalam memperkenalkan pelayanan jasa apa saja yang ditawarkan kepada konsumen.

3. Mampu menarik perhatian banyak orang sehingga Haikel Tenda semakin banyak dikenal.

4. Dapat menambah ilmu dan pengetahuan pembaca terutama dalam bidang sistem imformasi berbasis web.

\section{Metode}

Selama proses pengamatan dan pengumpulan bahan dalam penulisan skripsi ini, ada beberapa metode pembuatan yaitu sebagai berikut :

a. Penelitian Lapangan ( Field Research)

Yaitu penelitian yang dilakukan dengan cara pengamatan langsung ke lapangan mengenai setiap aspek - aspek yang ingin diteliti.Dalam hal ini melakukan proses pengumpulan data pada Haikel Tenda Banjarmasin,seperti data penyewaan tenda dan nama barang-barang apa saja yang disewakan .

b. Interview

Yaitu dengan cara bertemu langsung dengan pemilik Haikel tenda atau karyawan 
yang bertangung jawab dalam proses penyewaan kepada pelanggan dan proses pendataan serta laporan kepada pemilik.

c. Penelitian Perpustakaan

Yaitu dengan cara membaca , menganalisa, menyimpulkan dan mengutip bacaan-bacaan yang berhubungan dengan aspek yang diteliti.Bacaan -bacaan yang dibutuhkan diperoleh dari perpustakan sebagai bahan penunjang serta pembanding sehingga dapat memperoleh landasan landasan teori dari aplikasi yang dikembangkan.

d. Internet

Yaitu untuk memperoleh data secara online sehingga dapat menambah bahan referensi untuk aplikasi yang dikembangkan.

e. Analisa Data

Data yang diperoeh selanjutnya dianalisis untuk mengembangkan sistem yang ada dengan tujuan memperoleh hasil yang optimal.

\section{Tahapan Pembuatan}

Adapun langkah-langkah dalam pembuatan ini adalah :

1. Penentuan objek

2. Survey lokasi

3. Pengumpulan Data

4. Perancangan Desain Sistem

5. Pengolahan Data

6. Pembuatan Desain Program

7. Realisasi Perancangan Desain Sistem

8. Menganalisa Perancangan Sistem

9. Dokumentasi/Pembuatan Laporan

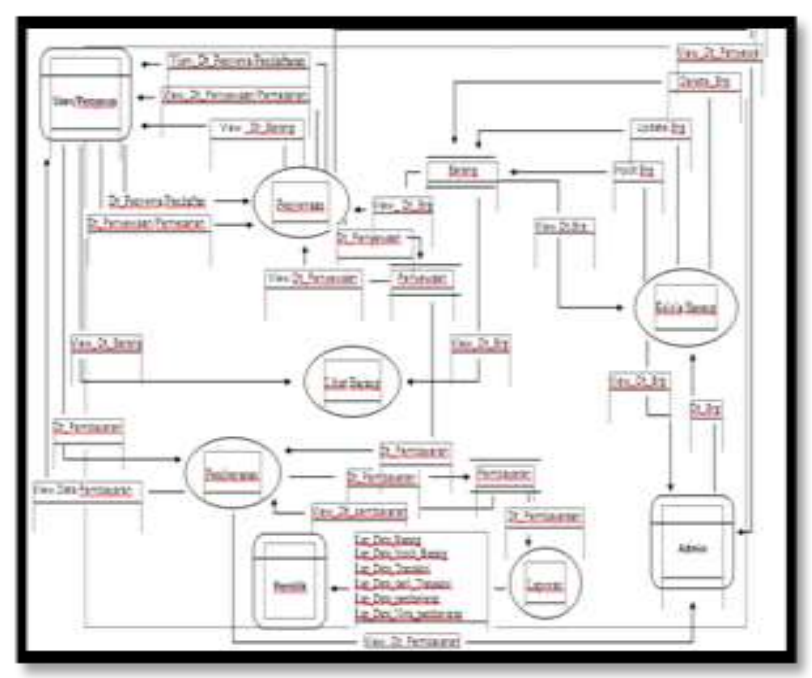

Gambar. DFD Level 1 Aplikasi Pemesanan Dan Penyewaan Tenda Berbasis Online Pada Haikel Tenda Banjarmasin Relasi Antar Tabel

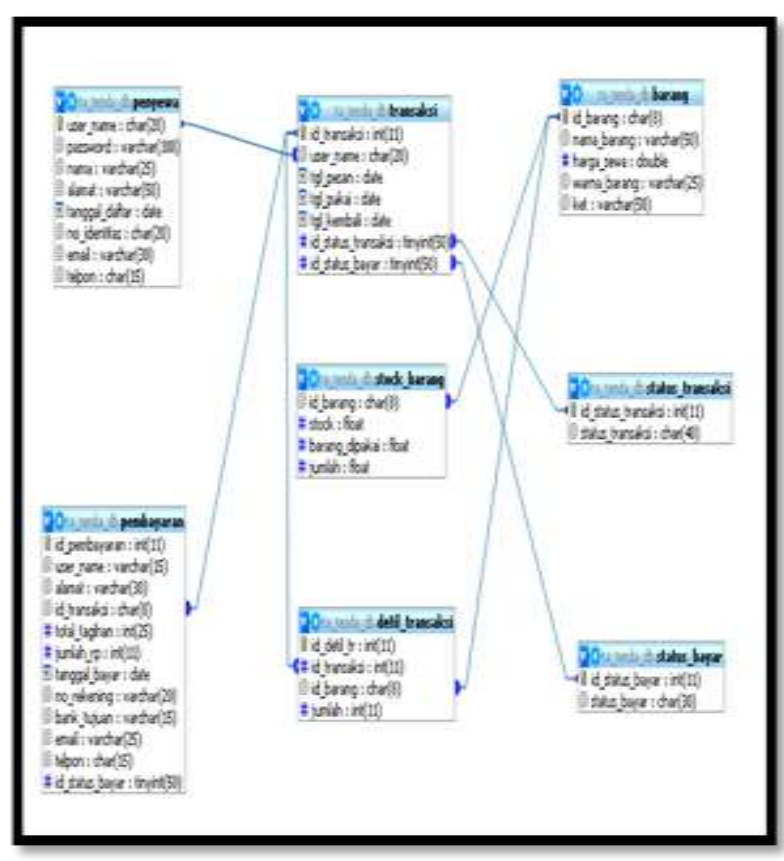

Gambar.Relasi Antar Tabel Sistem Informasi penyewaan dan pemesanan tenda

\section{Rancangan Form Menu Utama}

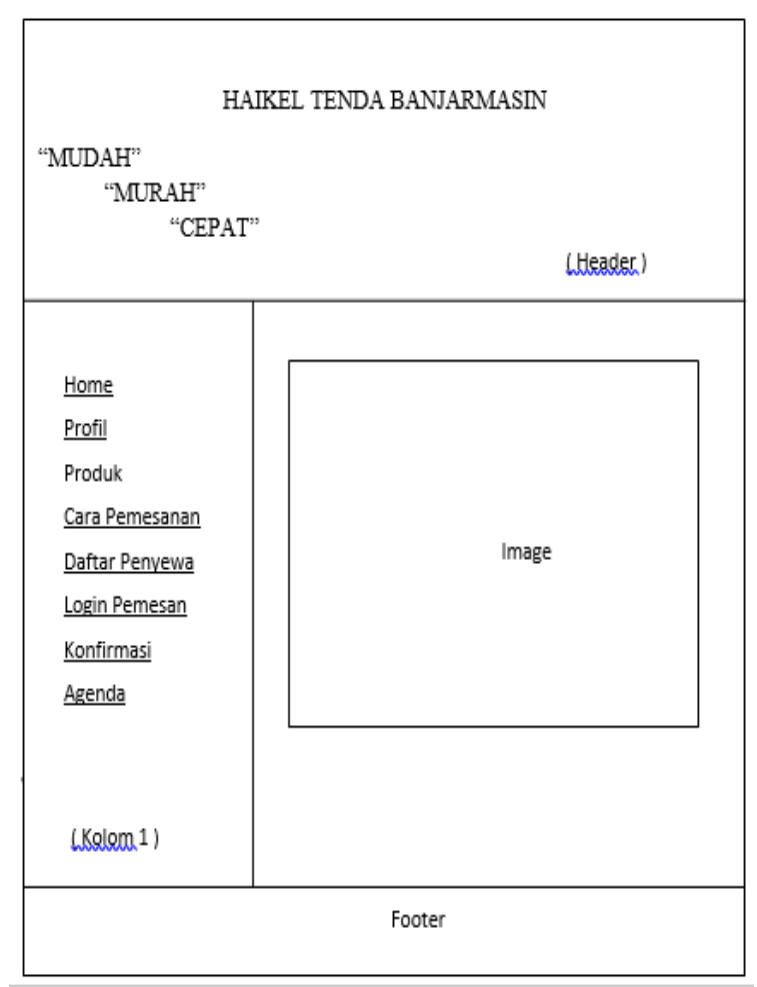




\section{Gambar. Rancangan Form Menu Utama}

\section{Tampilan Menu Utama}

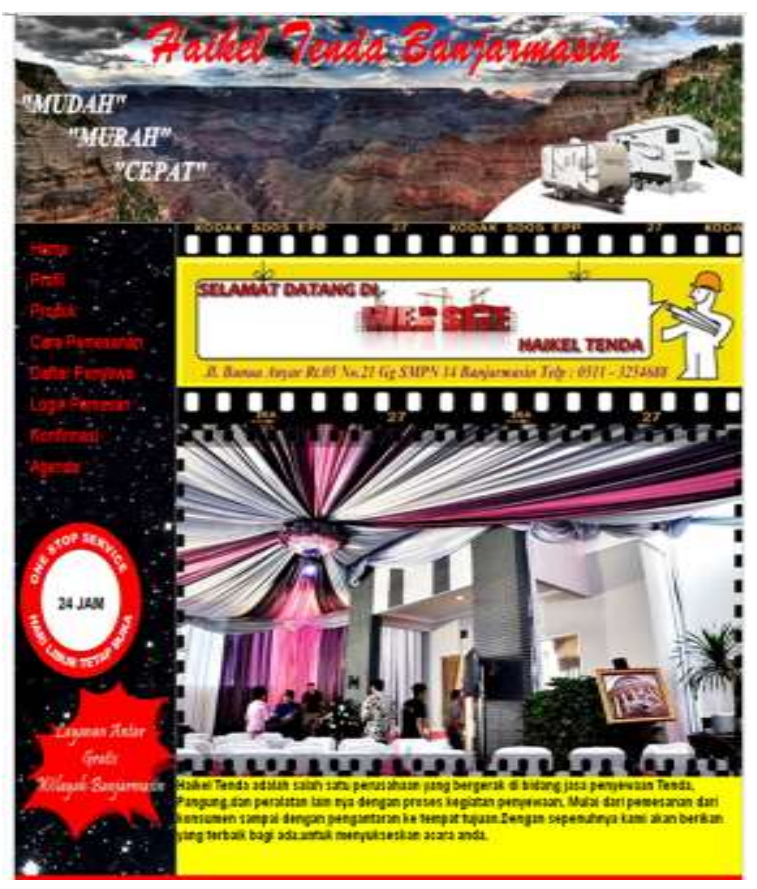

\section{Tampilan Menu Home Admin}

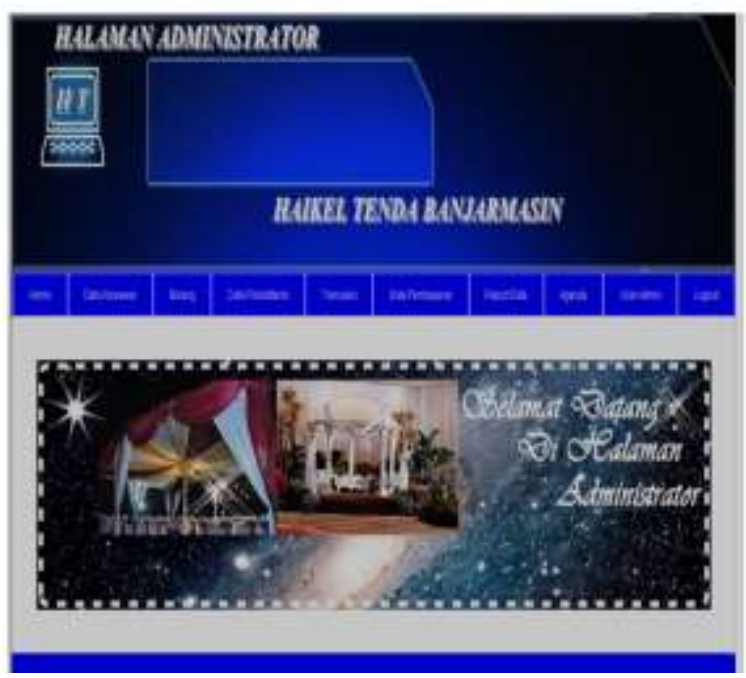

Berdasarkan dari hasil penulisan tentang pembuatan Aplikasi Pemesanan Dan Penyewaan Tenda Berbasis Online Pada Haikel Tenda Banjarmasin serta hasil pembahasan yang diuraikan pada bab-bab sebelumnya, maka dapat ditarik kesimpulan serta saran yang nantinya diharapkan berguna dan bermanfaat:

\section{Kesimpulan}

1. Dengan adanya aplikasi Penyewaan alat tenda,panggung,dan lain-lain yang berbasis Online ini, dapat membantu pelanggan yang akan menyewa untuk melakukan pemesanan secara online, tidak perlu membuang waktu untuk datang langsung ketempat penyewaan.

2. Memudahkan untuk memasarkan peralatan tenda dari perusahaan itu sendiri keseluruh masyarakat khususnya daerah Banjarmasin dan sekitarnya.

3. Memberikan kemudahan bagi admin untuk memberikan laporan kepada pemilik Haikel Tenda.

\section{Saran}

1. Dapat mempertahankan fungsinya sebagai sarana pembelajaran.

2. Penyewaan peralatan Tenda berbasis Online ini lebih baik di kembangkan lagi, seperti fitur penyewaan atau pembayaran secara online.

3. Diharapkan web ini tidak hanya diperuntukkan di wilayah Banjarmasin dan sekitarnya , dan bisa juga di akses di seluruh kabupaten kota Provinsi Kalimantan Selatan. 


\section{REFERENSI}

[1] Abdul Gafur, 2006, Resep Css(cascading style sheet),Dian Rakyat,Jakarta.

[2] Jogiyanto, 1995, Konsep Dasar Sistem dan Informasi, Andi Offset, Yogyakarta.

[3] Prahasta, Eddy, 2001, Konsep-konsep Dasar Sistem Informasi Geografis, Informatika, Bandung

[4] Sunarfrihantono Bimo, ST, PHP dan MySQL untuk Web, Andi Offset, Yogyakarta, 2002

[5] Sholikhin Akhmad, 2013. Pembangunan Sistem Informasi Inventarisasi Sekolah Pada Dinas Pendidikan Kabupaten

Rembang Berbasis Web 